\title{
Interrelatedness between Organizational Culture and Human Resource Management in the Context of Corporate Entrepreneurship
}

\author{
Syafri Naldi ${ }^{1 *}$; Dapit Alexsander²; Margo Purnomo ${ }^{3}$ \\ 1,2,3 Department of Business Administration, Universitas Padjadjaran \\ J1. Raya Bandung Sumedang KM. 21, Jatinangor, Sumedang, Jawa Barat 45363, Indonesia \\ ${ }^{1}$ syafri19001@mail.unpad.ac.id; ${ }^{2}$ dapit19001@mail.unpad.ac.id; ${ }^{3}$ purnomo@unpad.ac.id
}

Received: $26^{\text {th }}$ January 2021/ Revised: $07^{\text {th }}$ March 2021/ Accepted: $12^{\text {th }}$ March 2021

\begin{abstract}
How to Cite: Naldi, S., Alexsander, D., \& Purnomo, M. (2021). Interrelatedness between organizational culture and human resource management in the context of corporate entrepreneurship. The Winners, 22(1), 31-38.

https://doi.org/10.21512/tw.v22i1.6996
\end{abstract}

\begin{abstract}
There has been numerous research on corporate entrepreneurship typically referring to organizational culture or human resource management (HRM). The research aimed to complement previous research that had explored the link between entrepreneurship, the culture of organization, and HRM. The purpose of the research was to explain the operationalization of the three principles and to elaborate the interrelationship between them in the context of corporate entrepreneurship. The research used a systematic review process, namely an indepth literature review of results from 25 articles based on certain keywords and limitations. The result produces a model that describes the influence of HRM on organizational culture, which is expected to inspire businesses to adopt an approach to corporate entrepreneurship and enhance the efficiency of the company. Future research is suggested to have more than one database and use more research article sources published in over 10-20 years. It is expected that future research come up with extended range of observations and results on how science has progressed.
\end{abstract}

Keywords: organizational culture, human resource management, corporate entrepreneurship

\section{INTRODUCTION}

Market rivalry is currently very strong and lively, leading to confusion and business mistrust of traditional management practices. Companies are obliged to compel corporate entrepreneurship to solve this (Kassa \& Raju, 2020). Many factors can describe how entrepreneurial a business is, but creativity is one thing that always occurs in the discussion of this phrase (Fiordelisi et al., 2019). The corporate entrepreneurship issue has been around since the 1980s. For creativity, organizational renewal, redefining organisations, establishing and retaining competitive advantage, these elements also include behavioral details (Kuratko \& Hornsby, 2020). In the literature of corporate entrepreneurship, the four dimensions that frequently appear are: 1) corporate venturing, 2) creativity, 3) self-renewal, and 4) constructive (Ratten, 2018).

Corporate entrepreneurship needs the appropriate organizational culture (Tajpour \& Hosseini, 2019). Organizational culture at different levels may influence the actions of participants, both workers and executives. One of them helps workers to develop their skills and optimally take advantage of possibilities (Rashedi, 2019). The aspects of organizational culture are discussed in many research. Some views indicate that the dimensions of organizational culture includes creativity and human interaction (Aldhobaib, 2020; Hassan, Rhee, \& Dedahanov, 2019), bureaucracy, purpose, adaptability, continuity (Beigh et al., 2020), contact and engagement (Insan \& Masmarulan, 2021).

Human resource management is not only an organizational culture, but also an important factor that cannot be overlooked. The success of an organization can be seen from the capacity of the company to establish and leverage competencies in human resources. In fact, human resource management is said to be a source of sustainable competitive advantage for a company or corporation (Ebrahimi et al., 2020). The viewpoint of human resource management typically focuses on programs, networking, recruiting, training and development, and production (Hinteregger, 2017).

There is a significant connection between organizational culture and corporate entrepreneurship 
in several points of view. (Arz, 2017; Umrani, Kura, \& Ahmed, 2018; Üstün \& Kiliç, 2017). The key factor influencing entrepreneurial operations in an enterprise is organizational culture. Similar thing goes for the handling of human resources. Human resource management has a huge effect on corporate entrepreneurship (Castrogiovanni, Urbano, \& Loras, 2021; Salamzadeh, Tajpour, \& Hosseini, 2019) since it is the key vehicle that encourages activities and promotes corporate entrepreneurship (Burger \& Blažková, 2020; Lee, 2020).

It can be concluded from these statements that a reciprocal relationship exists between organizational culture and human resource management. While there is empirical evidence that human resource management and organizational culture play a role in corporate entrepreneurship, the interconnection between these factors has not been clearly defined. As a result, knowledge of the interplay between organizational culture, human resource management, and corporate entrepreneurship is limited. The research aims to examine the organizational culture and human resource management in corporate entrepreneurship and to explain the interplay between these elements. More precisely, the research intends to be useful in conducting studies on similar subjects related to organizational culture, human resource management, and corporate entrepreneurship.

\section{METHODS}

The research uses a commissioned systematic analysis (Tikito \& Souissi, 2019). Systematic analysis is a 'fundamental science practice' aimed at tracking bias by performing detailed activities ranging from reviews, decision-making, methods, debate and reports to in-depth literature searches of published scientific articles. Meta-analysis, which plays a major role in providing a statistical method to synthesize results, is one of the systematic review procedures.

The research adopts an approach used by Wu \& $\mathrm{Wu}$ (2019) in the course of reviewing this literature, including the steps of the research method provided in Figure 1.

The first step is to decide the research questions and identify keywords (Burger \& Blažková, 2020; Gomezelj, 2016). The goal of the research is to look at the relationship in corporate entrepreneurship between organizational culture and human resource management. The research questions in this systematic review focus on the priorities as seen in Figure 1.

Based on the research questions, the search keywords in the database include intrapreneurship, organizational culture, corporate culture, human resource management, creativity, organizational entrepreneurship, corporate entrepreneurship, corporate enterprises, corporate ventures, and revival of strategy. In addition, in the SpringerLink database, the search string has been set as shown in Table 1, along with the search results. Springer online databases is collected since the site includes integrated and trusted international scientific journals and publications from different disciplines. On October 28, 2020, the search took place. The research articles have been searched by means of the SpringerLink online database published in 2010-2020. To see the most recent research trends, the researchers selected 2020 and ten years back as it is considered not too short to see the evolution of research in organizational culture, human resource management, and corporate entrepreneurship. Besides, if the taking period is longer, it will result

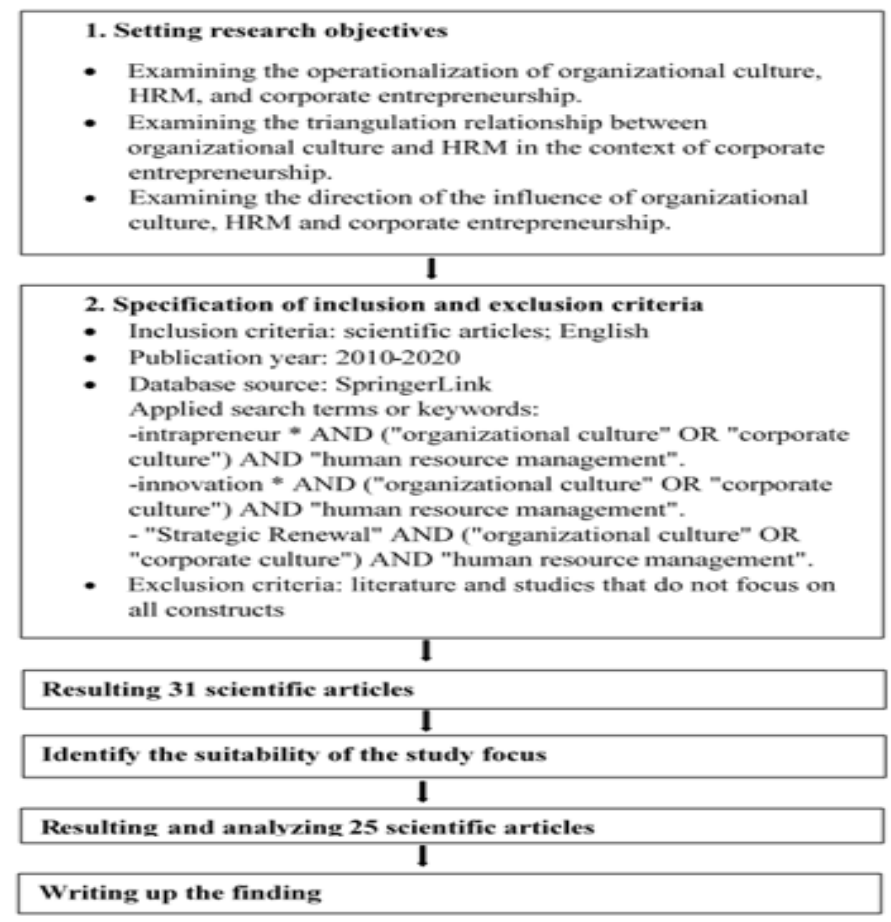

Figure 1 The Steps of the Research Method 
Table 1 Search Results on the SpringerLink Database

\begin{tabular}{|c|c|c|c|c|}
\hline No. & Search String & $\begin{array}{l}\text { Search Result } \\
\text { Outcome }\end{array}$ & $\begin{array}{l}\text { Complies electronically } \\
\text { with inclusion } \\
\text { requirements }\end{array}$ & $\begin{array}{c}\text { Assessment of } \\
\text { significance based } \\
\text { on community } \\
\text { discussion } \\
\end{array}$ \\
\hline 1. & $\begin{array}{l}\text { intrapreneur* AND ("organizational } \\
\text { culture" OR "corporate culture") AND } \\
\text { "human resource management" }\end{array}$ & 74 & 3 & 3 \\
\hline 2. & $\begin{array}{l}\text { innovation* AND ("organizational culture" } \\
\text { OR "corporate culture") AND "human } \\
\text { resource management" }\end{array}$ & 3148 & 90 & 23 \\
\hline 3. & $\begin{array}{l}\text { ("Organizational entrepreneur*" } \\
\text { OR "corporate entrepreneur") AND } \\
\text { ("organizational culture" OR "corporate } \\
\text { culture") AND "human resource } \\
\text { management" }\end{array}$ & 0 & 0 & 0 \\
\hline 4. & $\begin{array}{l}\text { ("Organizational venture*" OR "Corporate } \\
\text { venture*") AND ("organizational venture" } \\
\text { OR "corporate venture") AND "human } \\
\text { resource management" }\end{array}$ & 0 & 0 & 0 \\
\hline 5. & $\begin{array}{l}\text { "Strategic Renewal" AND ("organizational } \\
\text { culture" OR "corporate culture") AND } \\
\text { "human resource management" }\end{array}$ & 325 & 10 & 5 \\
\hline
\end{tabular}

in more posts which will, in turn, requires a longer research time.

Second, inclusion and exclusion requirements are set as follows: 1) Scientific publication in the form of publications from journals, 2) In corporate entrepreneurship, scientific papers address organizational culture and human resource management, 3) English articles, 4) Pertinent research. Relevance is assessed by group discussions of researchers through reading the entire article content. The research are sorted by removing the ones that do not follow the requirements, such as lecture articles or other non-journal articles, articles that address one of the key topics only, and articles that are not written in English. Following this point, 25 research articles are selected and discussed.

\section{RESULTS AND DISCUSSIONS}

The outcomes of the systematic analysis are divided into four parts. First, there are discussions on publication of the journal and the characteristics of the samples used. The second part identifies the operationalization of organizational culture, Human Resource Management (HRM), and corporate entrepreneurship. Third, in the sense of corporate entrepreneurship, the research explores the mediating role of organizational culture and HRM. The final part explains the mechanism of interference that influences the reciprocal relationship between the three variables.

The key sources of the journal come from Frontiers of Business Research in China, Service
Business, Journal of Business Economics, and Zeitschrift fur Betriebswirtschaft. During 2010 to 2020, research related to organizational culture, HRM, and corporate entrepreneurship had been published mostly in 2019, and at least in 2014 and 2015, while there had been no single publication related to the subject in 2016 (see Figure 2). The distribution of data is shown in Figure 3 based on the methods, the form of businesses, and the subject under discussion. According to these statistics, the quantitative approach is the most commonly used, with a total of 12 publications with the most discussion topics on employee performance (5) as well as creativity and innovation (3). In addition, qualitative approaches, a blend of quantitative and qualitative, literature analyses, and systematic reviews are available. On the other hand, companies in general (8) and the service sector (7) are the most discussed forms of businesses (7). Both of them also spoke about creativity and innovation (3) as well as employee performance (2).

Based on Table 2 it can be seen that from 2010 to 2020 , research related to organizational culture, HRM, and corporate entrepreneurship had been mostly conducted in China and Germany. There are five research conducted in general which did not apply to one country since it only discusses literature review. Industrial fields that are the subject of numerous studies include the manufacturing sector (Brenk et al., 2019; Zhu, Liu, \& Chen, 2018), the service industry (Fernandes, Ferreira, \& Marques, 2013; Huang, 2014; Manca et al., 2018), health institutions (Nöhammer \& Stichlberger, 2019), educational institutions (Nöhammer \& Stichlberger, 2019), specialty in 
hospitality (Cheng, et al., 2018; Espino-Rodríguez \& Ramírez-Fierro, 2018), technology-based businesses (Jiao, Wei, \& Cui, 2010), small and medium-sized enterprises (Saunila et al., 2020), start-ups (Tumasjan, Strobel, \& Welpe, 2011), and companies in general (Petti \& Zhang, 2011; Song, Li, \& Qiu, 2010). Figure 3 provides the overview.

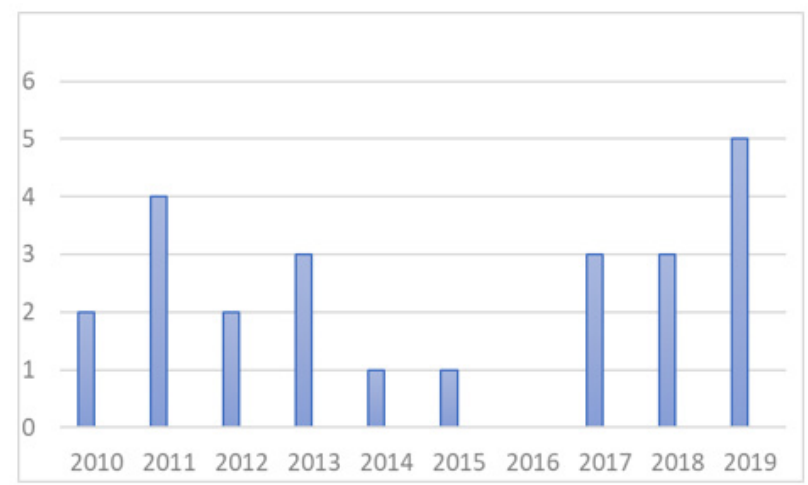

Figure 2 Number Per Year of Publications

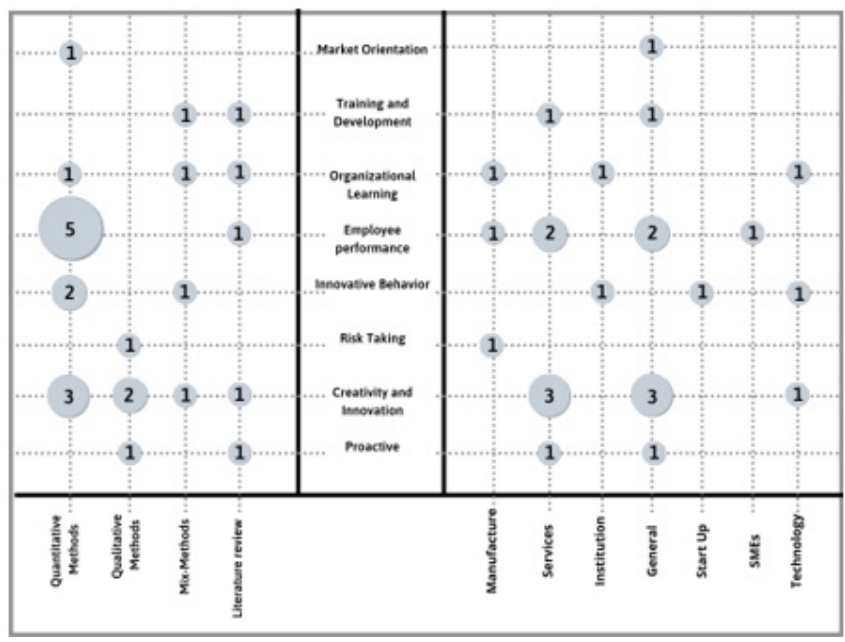

Figure 3 Data Distribution Centered on Research Methods, Business Types, and Topics Addressed

Table 2 Total of Publication by Nation

\begin{tabular}{ccc}
\hline No. & Country Name & Number of Publications \\
\hline 01. & Austria & 2 \\
02. & China & 7 \\
03. & Finland & 1 \\
04. & German & 5 \\
05. & Portugal & 1 \\
06. & Taiwan & 2 \\
07. & Spanish & 2 \\
08. & General & 5 \\
\hline
\end{tabular}

The complexities of conceptualization are demonstrated by the operationalization of organizational culture, HRM, and corporate entrepreneurship as it is used in different industries, such as technology, education, health, and so on. Organizational culture is an important attribute of work (Tumasjan et al., 2011), an intangible asset (Wang, 2011) in the form of attitudes, beliefs, experiences, and a management strategy that defines and guides the efforts of companies (Saunila et al., 2020 ) and is shaped by management-promoted values (Nöhammer \& Stichlberger, 2019). Organizational culture refers to the patterns of beliefs and perceptions that affect individual actions held by organizational members. Organizational culture often contributes to the development of expertise on the part of various staff members of different skills, in which strong and effective collaboration helps them to solve problems together and create synergistic results (Fernandes et al., 2013).

The organizational culture discussed in the reviewed article includes culture that encourages creative conduct (Nöhammer \& Stichlberger, 2019; Song et al., 2010), entrepreneurial culture or entrepreneurial orientation (Jiao et al., 2010; C Zhu et al., 2018) A creative culture stresses the embrace of more challenges and risks. Companies with certain cultural elements are more likely to innovate (Song et al., 2010). Entrepreneurial orientation can be seen as an organization's mentality that represents the attitude of entrepreneurship when starting a new company. Attitude is a central aspect of corporate culture that can be expressed in behaviors such as day-to-day activities and decision-making ( $\mathrm{Zhu}$ et al., 2018; Zhu, Liu, \& Wang, 2019). Furthermore, there is talk of business orientation culture. This organizational culture is considered to be the most productive and successful in developing the behaviors required for purchasers to build superior value and companies to achieve superior performance.

An accessible organizational culture positively affects the organization's creative capacity. The culture of uncertainty prevention is also critical for organizational decision-making (Song et al., 2010) and for technical entrepreneurial attitudes (Petti \& Zhang, 2011). The organizational culture that is established in hospitality is confidence and sharing, encouraging productive training and creating a fun learning atmosphere. Artists, workers and managers may identify with one another when hotels form an organizational culture of trust and cooperation. There is a harmonious corporate atmosphere for service companies such as hotels, in which workers should be encouraged to share and develop new information (Cheng et al., 2018).

Regarding HRM operationalization, by focusing on training and development, introducing an incentive system(for creative behavior), maintaining job security, offering autonomy, interesting task composition and adequate resources, HRM plays an important role in developing supportive settings for innovative work behavior. The need of work and ensuring feedback is welcomed (Nöhammer \& Stichlberger, 2019). HRM is linked to the success of businesses in recruiting, 
sustaining and retaining workers. A relationship that impacts each other is the resulting relationship. HRM will foster the entrepreneurial spirit of an organization through organizational learning (Zhu et al., 2019). Furthermore, organizational learning and HRM would promote the formation of dynamic skills (Jiao et al., 2010). In addition to the external environment, internal factors, organizational culture, information technology and so on, HRM is one of the factors affecting organizational learning (Zhu et al., 2019). Learning orientation can establish art-based highperformance human resource practices in servicebased businesses such as hotels to help workers develop skills, expertise, motivation and opportunities to provide fulfilling service (Cheng et al., 2018).

HRM is most frequently associated with highlevel performance processes or high-performance work systems (HPWS). This method is also known as high-performance work practices, high-commitment work systems, or high-involvement work systems, which is generally characterized as a collection of collaborative practices for managing human resources. The practices include scientific recruitment procedures, comprehensive training, authorization, decision-making engagement, performancebased compensation, and knowledge sharing. High-performance work systems can engage with organizational learning and create synergistic results to enhance organizational performance. Managers must also establish structured human resource strategies to devise strategic advantages and outperform market rivals (Zhu et al., 2019). HPWS represents strategic HRM's core theory and practice, and influences employees' perceptions, talents and actions by finding and using information to achieve organizational objectives (Zhu etal., 2018). Finally, HRM is associated with the resilience definition (Buliga, Scheiner, \& Voigt, 2016), associated with market performance information management techniques and IT strategies (Huang, 2014), and dedication. The dedication created by human resource (HR) activities will enhance efficiency by growing employees' willingness to work together to build and share information. In another way, human resource management has an impact on organizational efficiency (Saunila et al., 2020).

The application of corporate entrepreneurship is not explicitly mentioned by all research articles. In their clarification, some research addressing corporate entrepreneurship use the phrase creative or entrepreneurialorientation. Corporate entrepreneurship is also synonymous with learning and creativity, or with expertise. Corporate entrepreneurship through organizational learning will promote organizational success. The corporate entrepreneurship method turns new knowledge into new goods, processes or services, and only workers with special experience and entrepreneurial abilities can accomplish this. Thus, corporate entrepreneurship is deemed to improve workers' creative skill. Effectiveness is an effective approach to corporate entrepreneurship as it can cope with high volatility in corporate ventures and risky innovation initiatives (Brenk et al., 2019). Spin-alongs are organizational designs that can promote corporate entrepreneurship.

The complex design can help businesses navigate different innovation initiatives. A creative mindset or a passion for creativity is characterized by corporate entrepreneurship. Innovation potential is a strategic force defined by the orientation of consumers, the orientation of people, the existence of a plan for prospectors and the incentive of a manager to develop new services for underserved markets. (Hallak et al., 2018). Innovation is an essential part of competitive advantage (Saunila et al., 2020). It is believed that companies are to be imaginative, creative, cooperative, able to take chances and display engaging actions and appreciation for uncertainty (Tumasjan et al., 2011). They must be able to match service innovation with the strategic application of information technology in service-based businesses. Performance of service innovation serves as a portal for businesses to retain or capture the market, meet consumer expectations, accelerate service innovation success rates, and ensure business growth and profitability (Huang, 2014). In addition, businesses should aspire to use technological innovation since the entrepreneurial aspect of technological innovation is necessary for the effective production and promotion of a company's new product (Petti \& Zhang, 2011). It is believed that entrepreneurial orientation enhances efficiency. When creativity and entrepreneurship are promoted by the external environment and internal organizational policies, entrepreneurial orientation is positively linked to organizational efficiency. Moreover, dynamic price controls and risk-taking skills are essential to stay competitive in the global marketplace (Zhu et al., 2019).

In the context of corporate entrepreneurship, the results suggest a reciprocal connection between organizational culture and HRM. Organizational culture is said to facilitate successful training and create a fun learning environment (Jiao et al., 2010). Entrepreneurial culture and style of leadership may help employees to have loyalty and identity. Organizational culture often contributes to the development of expertise on the part of various staff members of different skills, in which strong and effective collaboration helps them to solve problems and produce synergistic results (Fernandes et al., 2013). This implies that corporate culture facilitates the development of HRM, which in turn affects team's success (Manca et al., 2018). These views suggest that HRM is a tool for companies to understand the ideals or culture of the company to achieve success.

HRM environments can foster an organizational culture that is entrepreneurially focused, such as a creative and constructive culture (Zhu et al., 2019) On the other hand, corporate entrepreneurship is influenced by HRM. Human skills have a huge effect on total production, productivity of labor, and efficiency of innovation (Saunila et al., 2020). People can increase their capabilities and generate innovations 
through HRM.

Organizational culture and HRM may also be influenced by corporate entrepreneurship. It is said that corporate culture, organizational structure, and/ or the external environment can affect the relationship between entrepreneurial orientation and company results, among other things (Cui et al., 2018). Entrepreneurial orientation has a significant effect on organizational culture, internal operating processes, organizational learning, and improved skills (Jiao et al., 2010). Entrepreneurial orientation can be seen as an organizational attitude that reflects entrepreneurial attitudes and desire to start a new company (Petti \& Zhang, 2011).

The research develops a model that demonstrates the connection between human resource management, organizational culture, and corporate entrepreneurship. In a nutshell, human resource management shapes and defines an organizational culture. A particular organizational culture demonstrates that the organization or company is committed to corporate entrepreneurship. Human resource management can also assist in the realization of corporate entrepreneurship. On the other hand, organizations that promote the idea of corporate entrepreneurship must have an organizational culture that embraces it, which would have an effect on human resource management. The interconnection model of these three concepts can be seen in Figure 4.

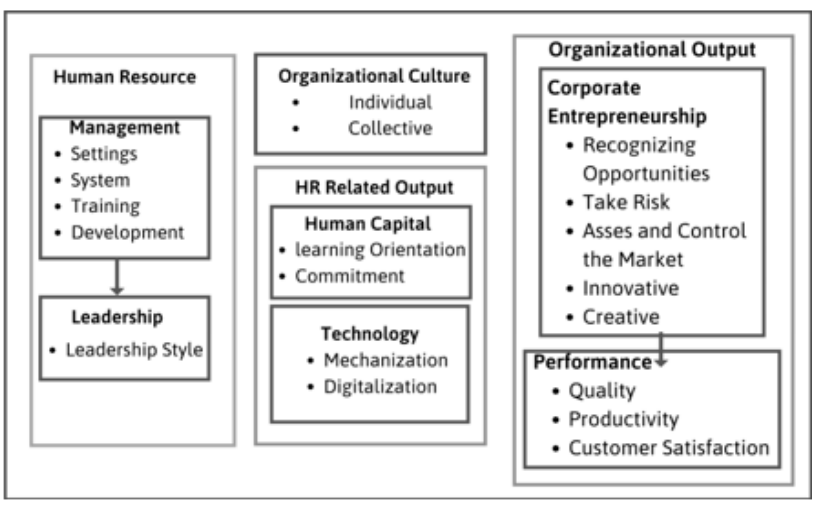

Figure 4 An Interconnection Model of Organizational Culture and HRM in the Context of Corporate Entrepreneurship

For all employees, an organization must have management in the form of settings, system, training, and development. This management takes on the role of a leader style. The characters that are created have an effect on the organizational culture, both individually and collectively. Learning orientation and commitment are two characteristics of an organizational culture that promotes corporate entrepreneurship. Corporate entrepreneurship can be realized with human capital (formed by HRM) that is geared toward learning and commitment, as well as developments in both mechanical and digital technology. Organizations that promote corporate entrepreneurship are risk-takers, market analysts and controllers, as well as innovative and creative thinkers. Companies that are good at running their businesses may typically be identified by their performance in terms of product or service quality, productivity, and customer satisfaction.

Corporate entrepreneurship is an ideology that allows employees to think and behave like entrepreneurs when working within the boundaries of today's corporate structure. Corporate entrepreneurship, in other words, fosters a particular organizational culture. Employees with the right vision and expertise are encouraged to pursue opportunities and develop ideas for new, innovative goods, services, or even business lines in corporate entrepreneurship.

\section{CONCLUSIONS}

Depending on the type of organization, the operationalization of organizational culture, HRM and corporate entrepreneurship, it is found that the implementation is different in each organization. Even so, it does not mean that there is little in common at all. It is frequently encountered that organizational culture facilitates an atmosphere of creative and entrepreneurial orientation. In servicebased organizations or enterprises, priority is given to service quality and learning-oriented organizational culture.

In the operationalization of HRM, learning orientation is a way to enhance skills by sharing information and continuing to learn. A highperformance work method that involves interactive HRM activities often occurs, including scientific recruiting processes, comprehensive training, authorization, decision-making involvement, performance-based rewards, and exchange of knowledge. Finally, in corporate entrepreneurship operationalization, innovation is correlated with the operationalization of this notion. In addition, it is also related to being innovative, willing to take risks, and able to analyze and influence the demand.

Corporate entrepreneurship, organizational culture and HRM have a reciprocal relationship. Organizational culture encourages the growth of HRM, while organizational culture may be strengthened by HRM. These two principles both inspire businesses to pursue an approach to corporate entrepreneurship. Organizational culture, HRM and corporate entrepreneurship eventually lead businesses to maximize their performance and boost the quality of the product, company productivity, and customer satisfaction.

The research can be established theoretically and methodologically. Theoretically, since every organization and business is fundamentally different from each other, the dimensions of the interconnection model of organizational culture and HRM in the sense of corporate entrepreneurship can be further established. Furthermore, the challenges facing organizations can change over time, affecting HRM environments and 
their organizational culture. Besides, the research can be methodologically built by other approaches, such as qualitative ones. The research subjects might not be as many as the quantitative research subjects in a qualitative approach, but the data and discussion might be more comprehensive and detailed.

Finally, the research, however, is subject to several limitations. First, since this analysis only uses one database source, the research articles reviewed only come from certain publishers. Second, the reviewed articles were written over a 10 -year period. It seems difficult to see how research on similar topics has progressed. Regarding systematic review literature, future research can use more than one database and use a longer publication period such as 15 or 20 years. It is expected that future research result in a wider range of observations and a better understanding of how science progresses.

\section{REFERENCES}

Aldhobaib, M. (2020). The interaction between organizational culture and individual behavior: A conceptual approach. Organizational Cultures, 20(2), 22. https://doi.org/10.18848/2327-8013/CGP/ v20i02/13-34.

Arz, C. (2017). Mechanisms of organizational culture for fostering corporate entrepreneurship: A systematic review and research agenda. Journal of Enterprising Culture, 25(4), 361-409. https://doi.org/10.1142/ S0218495817500145.

Beigh, J. N. S., Akin, D., Gerstner, T., Ruhl, T., \& Lopez, Y. P. (2020). Working in an adaptive organizational culture, is change easier to take? Academy of Management Proceedings. https://doi.org/10.5465/ AMBPP.2020.14098abstract.

Brenk, S., Lüttgens, D., Diener, K., \& Piller, F. (2019). Learning from failures in business model innovation: solving decision-making logic conflicts through intrapreneurial effectuation. Journal of Business Economics, 89, 1097-1147. https://doi.org/10.1007/ s11573-019-00954-1

Buliga, O., Scheiner, C. W., \& Voigt, K.-I. (2016). Business model innovation and organizational resilience: towards an integrated conceptual framework. Journal of Business Economics, 86(6), 647-670. https://doi.org/10.1007/s11573-015-0796-y.

Burger, L. \& Blažková, I. (2020). Internal determinants promoting corporate entrepreneurship in established organizations: A systematic literature review. Central European Business Review, 9(2), 19-45. https://doi. org/10.18267/j.cebr.233.

Castrogiovanni, G., Urbano, D., \& Loras, J. (2021). Linking corporate entrepreneurship and human resource management in SMEs. International Journal of Manpower, 32(1), 34-47.

Cheng, J.-S., Xiang, Y., Sher, P. J., \& Liu, C.-W. (2018). Artistic intervention, intellectual capital, and service innovation: a case study of a Taiwan's hotel. Service Business, 12(1), 169-201. https://doi.org/10.1007/ s11628-017-0342-9.

Cui, L., Fan, D., Guo, F., \& Fan, Y. (2018). Explicating the relationship of entrepreneurial orientation and firm performance: Underlying mechanisms in the context of an emerging market. Industrial Marketing Management, 71, 27-40. https://doi.org/10.1016/j. indmarman.2017.11.003.

Ebrahimi, E., Ghafourian, A., Isfahani, S., \& Ghafourian Shagerdi, M. S. (2020). The relationship between electronic human resource management, human resource flexibility, and creating a competitive advantage in hospital services. Journal of Health Administration, 23(3), 75-84. https://doi. org/10.29252/jha.23.3.75.

Espino-Rodríguez, T. F. \& Ramírez-Fierro, J. C. (2018). Dimensions of behavior and proactive improvement in hotel outsourcing relationships: the role of justice. Service Business, 13, 479-508. https://doi. org/10.1007/s11628-018-00392-z.

Fernandes, C., Ferreira, J. J., \& Marques, C. S. (2013). Innovation management capabilities in rural and urban knowledge intensive business services: empirical evidence. Service Business, 9, 233-256. https://doi.org/10.1007/s11628-013-0225-7.

Fiordelisi, F., Renneboog, L., Ricci, O., \& Lopes, S. S. (2019). Creative corporate culture and innovation. Journal of International Financial Markets, Institutions and Money, 63. https://doi.org/10.1016/j. intfin.2019.101137.

Gomezelj, D. O. (2016). A systematic review of research on innovation in hospitality and tourism. International Journal of Contemporary Hospitality Management, 28(3), 516-558. https://doi.org/10.1108/ IJCHM-10-2014-0510.

Hallak, R., Assaker, G., O’Connor, P., \& Lee, C. (2018). Firm performance in the upscale restaurant sector: The effects of resilience, creative self-efficacy, innovation and industry experience. Journal of Retailing and Consumer Services, 40, 229-240. https://doi.org/10.1016/j.jretconser.2017.10.014.

Hassan, N., Rhee, J., \& Dedahanov, A. (2019). Organizational culture influences on creativity and innovation: A review. Global Political Review, 4, 33 45. https://doi.org/10.31703/gpr.2019(IV-II).04.

Hinteregger, C. (2017). Integrating organisational culture and human resource management in the context of corporate entrepreneurship: A review and research agenda. International Journal of Business Environment, 9(2), 152-181. https://doi.org/10.1504/ IJBE.2017.085352.

Huang, H.-L. (2014). Performance effects of aligning service innovation and the strategic use of information technology. Service Business, 8, 171-195. https:// doi.org/10.1007/s11628-013-0192-z.

Insan, A. N. \& Masmarulan, R. (2021). Effects of leadermember exchange and organizational culture on work engagement and employee performance. Management Science Letters, 11, 879-886. https:// doi.org/10.5267/j.msl.2020.10.011.

Jiao, H., Wei, J., \& Cui, Y. (2010). An empirical study on paths to develop dynamic capabilities: From 
the perspectives of entrepreneurial orientation and organizational learning. Frontiers of Business Research in China, 4(1), 47-72. https://doi. org/10.1007/s11782-010-0003-5.

Kassa, A. G. \& Raju, R. S. (2020). Corporate entrepreneurship and innovation. European Journal of Business and Management, 6(31), 50-87. https:// www.researchgate.net/publication/344161780 Corporate_Entrepreneurship_and_Innovation.

Kuratko, D. \& Hornsby, J. (2020). New Venture Management: The Entrepreneur's Roadmap for Development, Management, and Growth. New York: Routledge. https://doi.org/10.4324/9781003034292.

Lee, H. (2020). Role of artificial intelligence and enterprise risk management to promote corporate entrepreneurship and business performance: evidence from korean banking sector. Journal of Intelligent \& Fuzzy Systems, 39(4), 5369-5386. https://doi.org/10.3233/JIFS-189022.

Manca, C., Grijalvo, M., Palacios, M., \& Kaulio, M. (2018). Collaborative workplaces for innovation in service companies: barriers and enablers for supporting new ways of working. Service Business, 12, 525-550. https://doi.org/10.1007/s11628-017-0359-0.

Nöhammer, E. \& Stichlberger, S. (2019). Digitalization, innovative work behavior and extended availability. Journal of Business Economics, 89(8-9), 1191-1214. https://doi.org/10.1007/s11573-019-00953-2.

Petti, C. \& Zhang, S. (2011). Explaining technological innovation in Chinese enterprises: Insights from technological entrepreneurship. Frontiers of Business Research in China, 5(3), 452-471. https:// doi.org/10.1007/s11782-011-0140-5.

Rashedi, H. (2019). Developing an effective organizational culture on organizational entrepreneurship in Tabriz University of Medical Science. SSRN Electronic Journal. https://doi.org/10.2139/ssrn.3500533.

Ratten, V. (2018). Corporate entrepreneurship. In V. Ratten, Sports Innovation Management. Routledge. https:// doi.org/10.4324/9781315177977-7.

Salamzadeh, A., Tajpour, M., \& Hosseini, E. (2019). Corporate entrepreneurship in University of Tehran: Does human resources management matter. International Journal of KnowledgeBased Development, 10(3), 276-292. https://doi. org/10.1504/IJKBD.2019.103218.

Saunila, M., Ukko, J., Rantala, T., Nasiri, M., \& Rantanen, H. (2020). Preceding operational capabilities as antecedents for productivity and innovation performance. Journal of Business Economics, 90(4), 537-561. https://doi.org/10.1007/s11573-01900963-0.

Song, D., Li, D., \& Qiu, L. (2010). The relationship between CIO's presence in the top management team and IT's contribution to corporate innovation: An empirical study. Frontiers of Business Research in China, 4(4), 685-701. https://doi.org/10.1007/s11782-0100116-X.

Tajpour, M. \& Hosseini, E. (2019). The effect of intelligence and organizational culture on corporate entrepreneurship in Shiraz Gas Compa. Human Resource Management in Oil Industry, 12(45), 335354. http://iieshrm.ir/article-1-927-en.html.

Tikito, I. \& Souissi, N. (2019). Meta-analysis of systematic literature review methods. International Journal of Modern Education and Computer Science, 11(2), 17-25. https://doi.org/10.5815/ijmecs.2019.02.03.

Tumasjan, A., Strobel, M., \& Welpe, I. M. (2011). Employer brand building for start-ups: which job attributes do employees value most? Zeitschrift Für Betriebswirtschaft, 81(S6), 111-136. https://doi. org/10.1007/s11573-011-0507-2.

Umrani, W. A., Kura, K. M., \& Ahmed, U. (2018). Corporate entrepreneurship and business performance: The moderating role of organizational culture in selected banks in Pakistan. PSU Research Review, 2(1). 5980. https://doi.org/10.1108/PRR-12-2016-0011.

Üstün, F. \& Kiliç, K. C. (2017). The effects of tightnesslooseness in organizational culture on corporate entrepreneurship and firm performance: A regional study in Turkey. Journal of Human Sciences, 14(4), 3866-3878. https://doi.org/10.14687/jhs.v14i4.4933.

Wang, M. (2011). Measuring intellectual capital and its effect on financial performance: Evidence from the capital market in Taiwan. Frontiers of Business Research in China, 5(2), 243-265. https://doi. org/10.1007/s11782-011-0130-7.

Wu, Y. \& Wu, S. (2019). Managing ambidexterity in creative industries: A survey. Journal of Business Research, 69(7), 2388-2396. http://dx.doi.org/10.1016/j. jbusres.2015.10.008.

Zhu, C, Liu, A., \& Chen, G. (2018). High performance work systems and corporate performance: the influence of entrepreneurial orientation and organizational learning. Frontiers of Business Research in China, 12(4). https://doi.org/10.1186/s11782-018-0025-y.

Zhu, C., Liu, A., \& Wang, Y. (2019). Integrating organizational learning with high-performance work system and entrepreneurial orientation: a moderated mediation framework. Frontiers of Business Research in China, 13(11). https://doi.org/10.1186/ s11782-019-0057-y.

Zhu, F., Wei, Z., Bao, Y., \& Zou, S. (2019). Base-of-thePyramid (BOP) orientation and firm performance: A strategy tripod view and evidence from China. International Business Review, 28(6). https://doi. org/10.1016/j.ibusrev.2019.101594. 